\title{
SCREENING FOR ANTI-QUORUM SENSING AND ANTI-BIOFILM ACTIVITY IN Viscum album L. EXTRACTS AND ITS BIOCHEMICAL COMPOSITION
}

\author{
Demet ERDÖNMEZ ${ }^{1 *}$, Nihal KENAR ${ }^{1}$, Kübra ERKAN TÜRKMEN ${ }^{2,3}$ \\ ${ }^{1}$ Aksaray University, Faculty of Science \& Letters, Department of Biology, 68100, Aksaray, TURKEY \\ ${ }^{2}$ Hacettepe University, Faculty of Science, Department of Biology, 06800, Ankara, TURKEY \\ ${ }^{3}$ Karamanoğlu Mehmetbey University, Kamil Özdağ Faculty of Science, Department of Biology, 70200, Karaman, TURKEY \\ *Corresponding author: ORCID ID: orcid.org/0000-0003-3955-1734, e-mail: demet.erdonmez@gmail.com
}

\section{Cite this article as:}

Erdönmez D., Kenar N., Erkan Türkmen K. 2018. Screening for Anti-Quorum Sensing and Anti-Biofilm Activity in Viscum album L. Extracts and Its Biochemical Composition. Trakya Univ J Nat Sci, 19(2): 175-186, DOI: 10.23902/trkjnat.369911

Received: 22 December 2017, Accepted: 13 October 2018, Published: 15 October 2018

\begin{abstract}
Many opportunistic pathogenic bacteria use the Quorum Sensing (QS) system to coordinate their virulence expressions. Thus, QS can likely be a new approach to control bacterial infections. The aim of this study was to evaluate the antimicrobial, anti-biofilm, and anti-quorum sensing activities of ethanol, chloroform, and dichloromethane: methanol extracts of leaf, stem, and fruits of the European mistletoe Viscum album L. on 2 Gram-positive and 7 Gram-negative pathogenic bacteria. The extracts at concentrations ranging from 50 to $250 \mathrm{mg} / \mathrm{ml}$ were tested depending on the extracts of the plant parts and the test bacteria. The extract with $50 \mathrm{mg} / \mathrm{ml}$ concentration, in which no antimicrobial activity was observed, was used for anti-quorum sensing and antibiofilm studies. The dichloromethane: methanol extracts were found to show the highest biological activities. QS activities of the plant extracts were also determined using the recently established Chromobacterium violaceum CV026 reporter strain and the signaling molecule $N$-(ß-ketocaproyl)-L-homoserine lactone (3-oxo-C6-HSL) agar well diffusion assay. Biofilm was quantified using the microtiter plate test and the crystal violet assay. Anti-microbial, anti-biofilm, and anti-quorum sensing activity of leaf and stem extracts showed higher efficiency than fruit extracts. It was concluded that the extracts of $V$. album had the potential to treat microbial infections by biofilm inhibition or inhibition of QS.
\end{abstract}

Key words: Anti-quorum sensing, Anti-biofilm activity, Antibacterial activity, Viscum album L.

Özet: Fırsatçı patojenik bakteriler, virülans ifadelerini koordine etmek için Quorum Sensing (QS) sistemini kullanır. Dolayısıyla QS sistemi, bakteriyel enfeksiyonların kontrolü için yeni bir yaklaşım olarak tercih edilebilir. Bu çalışmanın amacı, 2 Gram-pozitif, 7 Gram-negatif patojenik bakteri üzerinde analiz edilen Viscum album L. bitkisinin gövde, yaprak ve meyve gibi bölümlerine ait etanol, kloroform ve diklorometan:metanol ekstraktlarının antimikrobiyal, anti-biyofilm ve anti-quorum sensing aktivitelerinin değerlendirilmesidir. Kullanılan bitki parçası ekstraktına ve test mikroorganizmasına bağlı olarak, 50$250 \mathrm{mg} / \mathrm{ml}$ arasında değişen konsantrasyonlarda ekstraklar test edildi. $50 \mathrm{mg} / \mathrm{ml}$ 'lik konsantrasyonda antimikrobiyal aktivite görülmediği için anti-quorum sensing ve antibiyofilm çalışmalarında bu konsantrasyon kullanılmıştır. En iyi biyolojik aktivitenin görüldüğü çözücünün ise diklorometan:metanol olduğu saptandı. Ekstraktların anti-quorum sensing aktiviteleri, Chromobacterium violaceum CV026 biyosensör suşu ve sinyal molekülü N- ( $\beta$-ketokaproil) -L-homoserin lakton (3-okso-C6HSL)'nün bulunduğu besiyerinde agar difüzyon deneyi kullanılarak da tespit edilmiştir. Biyofilm, mikrotiter plaka testi ve kristal viyole kullanılarak ölçülmüştür. Yaprak ve gövde kısımlarının antimikrobiyal, anti-biyofilm ve anti-quorum sensing aktivitesi, meyve ekstraktına göre daha yüksek verimlilik göstermiştir. V. album özütlerinin, biyofilm ya da QS inhibisyonu yoluyla mikrobiyal enfeksiyonları tedavi etme potansiyeline sahip olduğu kanısına varılmıştır.

\section{Introduction}

Viscum album L. subsp. album (mistletoe), belonging to the family Santalaceae, is an evergreen plant growing semi-parasitically on its host. It is a Eurasian and North African species and its distribution in Turkey covers mainly the north, west, and south-west of Anatolia. Its leaves are opposite and parallel-veined, and its fruits are viscid berries. The epithet name of Viscum album in Latin was assigned to the plant considering the white color of the fruits (Ergun \& Deliorman 1995). Seed distribution of $V$. album is mediated by birds who achieve this task by eating the fruits and leaving their stools on trees. The seeds germinating on the host trees send out their rootlet to penetrate into the bark and absorb nutrients and water from the trees which are used by the growing plant. The 
high amount of loss in volume and diameter of the host trunk occurs due to this parasitic feature of $V$. album (Eroğlu \& Usta 1993).

Viscum album has long been known as one of the most magical, mysterious, and sacred plants in nature. Therefore, the use of $V$. album as a herbal medicine probably dates back to prehistoric times. The Druids of Britain used to harvest $V$. album from their sacred oaks to use them in rituals and medicine. Dioscorides (15-85 AC) and Hippocrates (460-377 BC) used it to treat diseases of the spleen and complaints of menstruation. Plinius (23-79 AC) was also reported to cure epilepsy, infertility, and ulcers using this plant. Celcus the Platonist remarked that mistletoe was used in the treatment of swellings or tumors (around $150 \mathrm{AC}$ ). Tabernaemontaunus stated that its leaves healed hepatitis, leprosy, and mumps. At the end of the $19^{\text {th }}$ century, mistletoe-containing ointment was reported to be effective in the treatment of eczema, burn diseases, and some wounds (Bussing 2003). V. album has also drawn attention as a possible anti-cancer agent since the 1920s (Habeck 2003). Although it is a parasitic plant, its medical importance has been gradually increasing due to the diverse phytochemicals that the plants contain such as lectins, viscotoxins, alcholoids, amines, amino acids, flavonoids, glycosides, lignans, carbocyclic acids, phenylpropanes, polypeptides, polysaccharides, sugar alcohols, polyphenolic, and terpenoid compounds all which are known to have rich biological activities (Deliorman et al. 2001, Arda et al. 2003, Sengul et al. 2009, Nazaruk \& Orlikowski 2016). However, the use of the European mistletoe $V$. album is common in medicine since the American mistletoe Phoradendron flavescens (Pursh Nutt.) is toxic (Ogunmefun et al. 2013). The compounds obtained from $V$. album are prevalently used for gastro-intestinal, diabetes, blood pressure problems, treatment of cancer, the hepatitis $\mathrm{C}$ virus (HCV), $\mathrm{HIV}$, and human parainfluenza virus type 2 (HPIV-2) (Stoss \& Gorter 1998, Tusenius et al. 2001, Karagöz et al. 2003), but the field of the use of the plant may vary based on the chemical properties of host tree which in turn affect compounds present in V. album.

Viscum album has been successfully used for the treatment of infection diseases in consequence of the effects of plant on microorganisms (Hussain et al. 2011). A bacterial infection begins with the organization of bacteria acting in unison (Rumbaugh et al. 2009, Antunes et al. 2010). This system is known as "Quorum-sensing" (QS) system (Waters \& Bassler 2005). Microorganisms cannot activate their resistance mechanisms if this step is blocked in the treatment of infection (Adonizio et al. 2006, Musthafa et al. 2010). Biofilms are thought to be associated with microbial infection and their formations are considered to be regulated by QS (Brackman \& Coenye 2015). Therefore, maturation and eradication of biofilms have great importance in fighting infection (Chung \& Toh 2014).

In the present study, we evaluated the anti-biofilm activities of ethanol, chloroform, and dichloromethane: methanol extracts of different parts of Viscum album against Listeria monocytogenes ATCC 7644, Staphylococcus epidermitis wt, Pseudomonas aeruginosa ATCC 27853, Klebsiella pneumoniae ATCC 700603, Proteus vulgaris Hauser, Pseudomonas aeruginosa PA14, Enterococcus faecalis ATCC 29212, Escherichia coli O157: H7, and Bacillus cereus RSKK 863 and the interaction of these plant extracts with bacterial QS. Viscum album was selected as the study material because of the wide use of natural and easily available herbal drugs obtained from it.

\section{Materials and Methods}

\section{Collection of V. album samples and extract preparation}

Viscum album samples collected at an altitude of $1475 \mathrm{~m}$ around Ihlara-Kulaköy in Aksaray province in October and November 2015 were used. The Flora of Turkey and The East Aegean Islands (Davis 1965) and The Checklist of the Flora of Turkey - Vascular Plants (Güner 2012) were used for identification of the plant specimens. Fresh plant samples were separated as leaves, stems, and fruits in sterile conditions in the laboratory and were left to dry at room temperature. Dried plant parts were grinded by a pulverizer, and $100 \mathrm{gr} / 500 \mathrm{ml}$ of each dry plant part was extracted with ethanol, chloroform, and dichloromethane:methanol (w/v) (at $60^{\circ} \mathrm{C}$ for $6 \mathrm{~h}$ ) in soxhlet apparatus. The extracts were then concentrated in a rotary evaporator after the residues had been centrifuged (at $3.000 \mathrm{~g}$ ) and washed with physiological saline solution for 5 minutes. The supernatants of the extracts were kept at $4{ }^{\circ} \mathrm{C}$ and used for future investigations. The residues were used for anti-quorum sensing and anti-biofilm experiments.

\section{Bacterial Strains and Culture Conditions}

The microorganisms used in the study were produced from the microbial culture collection kept in microbiology laboratory of Scientific and Technological Research Center of Aksaray University. Chromobacterium violaceum ATCC 12472 and C. violaceum CV026 strains used for anti-quorum sensing were kindly provided by Prof. Dr. Robert Mclean in Department of Biology, Texas State University-San Marcos, USA. Listeria monocytogenes ATCC 7644, Staphylococcus epidermitis wt, Pseudomonas aeruginosa ATCC 27853, Klebsiella pneumoniae ATCC 700603, Proteus vulgaris, Pseudomonas aeruginosa PA14, Enterococcus faecalis ATCC 29212, Escherichia coli O157: H7, and Bacillus cereus RSKK 863 were grown using the Brain Heart Infusion Broth (Merck) medium. Dichloromethane: methanol extracts were tested to determine if they had an effect on anti-quorum sensing and anti-biofilm activity of the strains.

\section{Phytochemical Analysis with GC-MS}

GC-MS analysis of $V$. album extracts $(100 \mathrm{mg} / \mathrm{ml})$ was carried out by 5975 Mass Selective Detector with Agilent 6890 GC, using HP-5 MS capillary column (30m x $250 \mu \mathrm{m} \times 0.25 \mu \mathrm{m}$ ) at a flow rate of $3 \mathrm{~mL}$ per minute, split mode injection (1:20), GC/MS interface at $280^{\circ} \mathrm{C}$ 
temperature, column temperature program as $50^{\circ} \mathrm{C}$ $(2 \mathrm{~min})-300^{\circ} \mathrm{C}$ to $5^{\circ} \mathrm{C} \mathrm{min}^{-1}(16 \mathrm{~min}) .1 .0 \mu \mathrm{L}$ of the diluted sample was manually injected in splitless mode. Identification of the compounds was made by NIST 14 and Wiley Libraries within the mass spectral databases of the device at ASÜBTAM (Aksaray University Scientific and Technological Application and Research Center).

\section{Antibacterial Activity Assays}

The antibacterial influence of Viscum album leaf, stem, and fruit extracts on the nine pathogenic bacteria were investigated by the agar well diffusion method. Each purified extract was dissolved in dimethyl sulfoxide and stored at $4^{\circ} \mathrm{C}$. The antibacterial activity of the substances was shown by a clear zone of inhibition around the application point. All bacterial strains were grown in Brain Heart Infusion Broth (Merck) for $24 \mathrm{~h}$ at $37^{\circ} \mathrm{C}$. The concentration of bacterial suspensions was adjusted to $10^{8} \mathrm{cells} / \mathrm{ml}$ in Brain Heart Infusion Broth and $100 \mu \mathrm{l}$ of each culture of bacteria was spread on agar plate surfaces. Wells $5 \mathrm{~mm}$ in diameter were opened on the agar with a cork borer to load $20 \mu \mathrm{l}$ of each sample incubated at $25^{\circ} \mathrm{C}$ for $3 \mathrm{~h}$. Gentamycin (10UI) was used as positive control, while Dimethyl sulfoxide (DMSO) was used as the negative control. The plates were incubated at $37^{\circ} \mathrm{C}$ for $24 \mathrm{~h}$ before they were examined for inhibition zones of growth. All tests were performed in triplicate.

\section{Antiquorum Sensing Activity Assay}

Plant extracts at a concentration of $50 \mathrm{mg} / \mathrm{ml}$ were used depending on the results of the antibacterial effects. The bacterial culture of $C$. violaceum CV026 biosensor strain, which was grown at $30^{\circ} \mathrm{C}$ for 15 hours, was adjusted to a McFarland standard $0.5\left(10^{6} \mathrm{CFU} / \mathrm{ml}\right)$. The ideal wavelength of the absorbance was established, the absorbance of the standards was measured, and the cell counting in UV-Vis spectrophotometrically was performed. Chromobacterium violaceum $\mathrm{CV} 026$ and the extract of $50 \mu 1 \mathrm{~N}$-(ß-ketocaproyl)-L-homoserine lactone (3-oxo-C6-HSL) on $10 \mathrm{ml}$ soft Luria Bertani (LB) agar medium was added for agar diffusion test. LB agar medium was prepared with $0.9 \%$ agar, $100 \mu \mathrm{l} C$. violaceum CV026, and $50 \mu 1 \quad N$-(B-ketocaproyl)-Lhomoserine lactone (3-oxo-C6-HSL) extract and after solidification, $4 \mathrm{~mm}$ diameter wells were scooped out from the LB agar medium. The wells were filled with the plant extracts $(50 \mathrm{mg} / \mathrm{ml})$ in different solvents. The agar plates were incubated at $30^{\circ} \mathrm{C}$ for 48 hours. Agar diffusion tests were also conducted in triplicate (Adonizio et al. 2006, Bezek et al. 2016, Oliveira et al. 2016).

\section{Violacein Pigment Isolation}

$100 \mu \mathrm{l}$ of $20 \mathrm{ml}$ of fresh C. violaceum CV026 strain grown LB medium in 15 hours was inoculated according to the procedure given in Table 1 for the extraction of violacein pigment from the liquid culture. The bacterial culture was incubated at $30^{\circ} \mathrm{C}$ for 24 hours and then vortexed. $200 \mu \mathrm{l}$ of the culture from the tube was transferred to a $1.5 \mathrm{ml}$ Eppendorf microcentrifuge tube.
$200 \mu \mathrm{l}$ of $10 \%$ sodium dodecyl sulfate (SDS) solution was added in the culture for cell fractionation, and the culture was kept at room temperature for 5 minutes after vortexing for 5 seconds. $900 \mu$ l of water-saturated butanol $(50 \mathrm{ml} \mathrm{n}$-butanol $+10 \mathrm{ml}$ distilled water) was added into the tube for violacein pigment isolation, and the tube was vortexed for 5 seconds. It was then centrifuged at 10,000 rpm for 5 minutes. The upper phase was transferred to a new tube. It was read spectrophotometrically at $595 \mathrm{~nm}$, and the amount of viola was determined (Khan 2009).

Table 1. Viscum album extract application procedure.

\begin{tabular}{lcccc}
\hline \hline & $\begin{array}{c}\text { Group } \\
\text { A }\end{array}$ & $\begin{array}{c}\text { Group } \\
\text { B }\end{array}$ & $\begin{array}{c}\text { Group } \\
\text { C }\end{array}$ & $\begin{array}{c}\text { Final } \\
\text { concentration }\end{array}$ \\
\hline \hline Luria Bertani Broth & $895 \mu 1$ & $890 \mu 1$ & $890 \mu l$ & \\
C. violaceum CV026 & $100 \mu 1$ & $100 \mu 1$ & $100 \mu 1$ & $1 \times 10^{8} \mathrm{cfu} / \mathrm{ml}$ \\
3-oxo-C6-HSL & $50 \mu 1$ & $50 \mu 1$ & $50 \mu 1$ & $150 \mu \mathrm{mol} / \mathrm{ml}$ \\
Viscum extracts & - & - & $5 \mu 1$ & $50 \mathrm{mg} / \mathrm{ml}$ \\
DMSO or Ethanol & - & $5 \mu 1$ & - & \\
Total volume & $1045 \mu 1$ & $1045 \mu 1$ & $1045 \mu 1$ & \\
\hline \hline
\end{tabular}

*Group $\mathrm{A}$ and $\mathrm{B}$ are the control groups. Group $\mathrm{C}$ is the experimental group.

$\underline{\text { Anti-biofilm Activity Assays }}$

Biofilm formation was confirmed with the Crystal Violet Method. The test bacteria which were incubated in Tryptic Soy Broth at $37^{\circ} \mathrm{C}$ for 24 hours were diluted according to Mc Farland 0.5 . $100 \mu 1$ of the bacterial cultures was inoculated in $5 \mathrm{ml}$ Tryptic Soy Broth (TSB) in a shaking incubator at $120 \mathrm{rpm}$ for 24 hours. Following the incubation, polystyrene microplates with 24 wells were filled with $900 \mu 1 \mathrm{TSB}$ medium $+50 \mu \mathrm{l}$ plant extract $(50 \mathrm{mg} / \mathrm{ml})+50 \mu \mathrm{l}$ test bacteria, and left at $37^{\circ} \mathrm{C}$ for 48 hours. The mediums were removed from microplates, and washed by $1 \times$ PBS buffer three times. The microplates were dried at $65^{\circ} \mathrm{C}$ in an incubator, and then were left to be dyed with $1 \%$ Crystal Violet for 2 minutes. The microplates were washed three times with distilled water at the end of the staining process and dried at room temperature. The Crystal Violet solutions in microplates solved by $30 \%$ acetic acid solution were read in the spectrophotometer at $595 \mathrm{~nm}$ against the control group. Thus, the ability of biofilm formation of the test bacteria was determined (Stepanović et al. 2000, Hoffman et al. 2005, O'Toole 2011, Kaya et al. 2016).

\section{Statistical analyses}

Arithmetic means and standard deviations of the obtained data were calculated in Microsoft Excel 2016.

\section{Results}

In recent years, despite the development of technology and medicine, the fight against the infection factors remains inadequate. This leads the scientists to the use of natural resources. The use of plant extracts in healthcare industry has recently gained popularity, and it is a prevalent application in not only in Turkey but also in 
many developing countries worldwide. Scientists have been interested in the availability of new compounds in plants which have not yet been discovered for the inhibition of anti-quorum sensing recently. The effects of compounds in plant extracts on microorganisms have been reported to vary according to the plant species, amount of plant parts in the extract, and their maturation.

The utilization of $V$. album in traditional medicine implies that it can also be used in modern medicine, especially in cancer and cardiovascular diseases (Gray \& Flatt 1999). According to epidemiological studies, essential oil and phenolic compounds have inhibitive effects against the progress of bacterial infections (Ghuman et al. 2016, Martinelli et al. 2017). GC-MS chromatogram analysis of leaf extracts of $V$. album showed different peaks, which indicates the presence of 8 main phytochemical constituents (Fig. 1), whilst the stem of $V$. album was found to include 10 main components (Fig. 2). These constituents were characterized and identified by comparing their mass spectra with the NIST library (Tables 2,3).

The GC-MS chromatogram analysis of fruit extracts showed that the content of fruit extracts appeared to be rich in some compounds such as 5-hidroximetilfurfural, glucose, Inositol, Palmitic acid, Stearic acid, p-coumaric acid, and phenolic components (Fig. 3). The identification and quantification of phenolic compounds in fruits were analyzed by the GC-MS analysis (Table 4). The overall results of the GC-MS analysis showed that both stem and leaf extracts contained polyphenolic compounds that are biologically more important compared to compounds in fruits. Although the fruit extracts of V. album appeared to be rich in antioxidant content, they should be used with caution because they have cytotoxic activity. The pharmacologically active chemical content of the V. album extracts varies depending on the host plant and the harvesting time (Büssing \& Schietzel 1999). In conclusion, this study revealed the anti-quorum sensing, antibiofilm, and antimicrobial activities of the main chemical components of the V. album.

Viscum album is known to possess healing properties and was successfully used in treatment applications of various infectious diseases in humans. The antibacterial activity of $V$. album stem and leaf extracts in our study was determined on different pathogenic bacteria. The results of the antimicrobial screening of fruit, stem and leaf extracts are shown in Tables 5 and 6 . The extracts prepared at concentrations of $150 \mathrm{mg} / \mathrm{ml}, 200 \mathrm{mg} / \mathrm{ml}$, and $250 \mathrm{mg} / \mathrm{ml}$ in methanol: dichloromethane, ethanol, and chloroform were shown to stop the bacterial growth.

The dichloromethane: methanol extract prepared at a concentration of $50 \mathrm{mg} / \mathrm{ml}$ inhibited only on Proteus vulgaris. In general, it was found that the effectiveness of chloroform and ethanol extracts prepared at $150 \mathrm{mg} / \mathrm{ml}$ concentration on bacteria was lower, but the efficiency of the same concentration of dichloromethane: methanol extract on bacterial growth was higher.

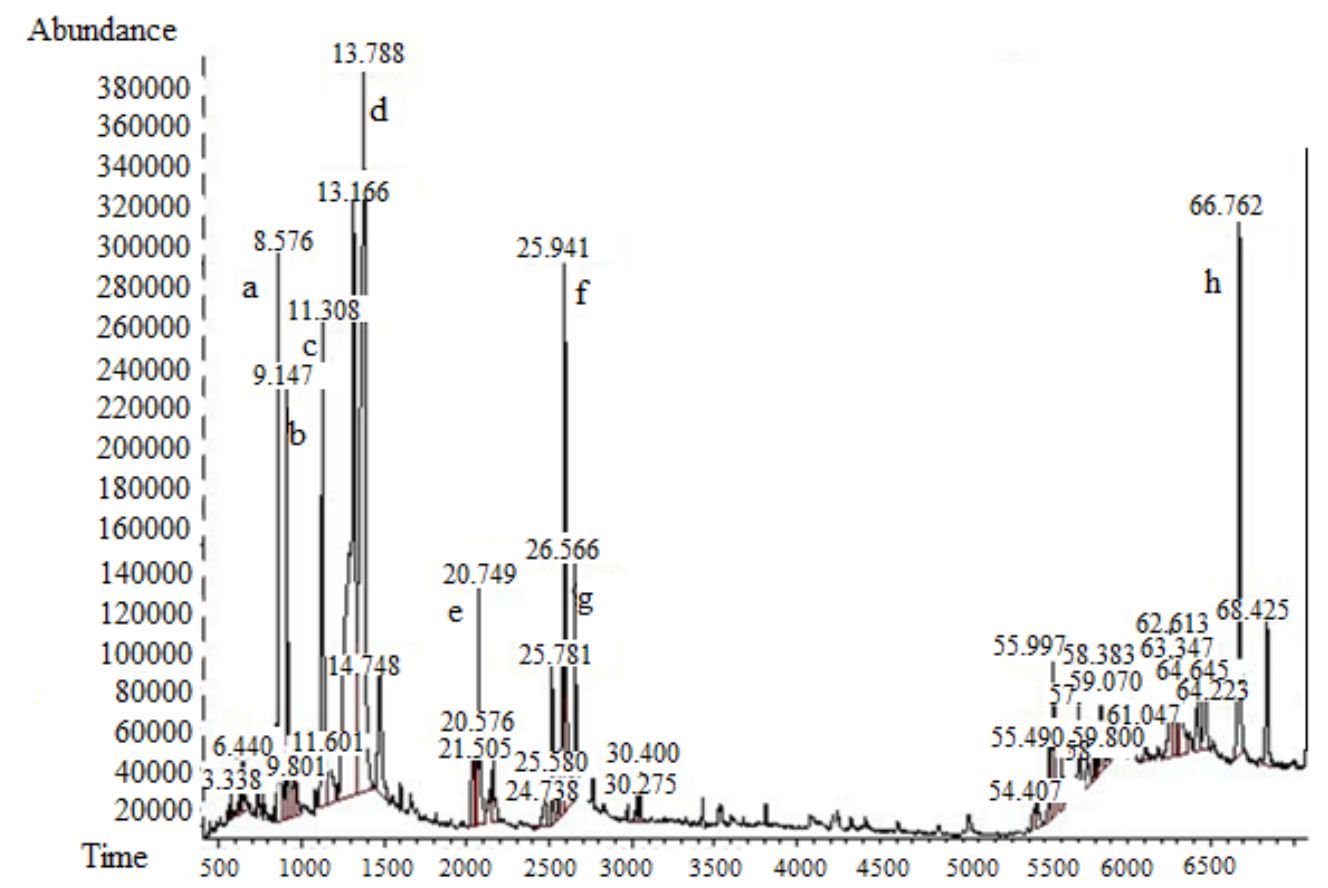

Fig. 1. GC-MS analysis of V. album leaf extracts. Main components: (a) Trans-cinnamic acid, (b) 3,5-Dimethoxyphenol, (c) Thiophane, propyl-, (d) Ethoxycitronellal, (e) Palmitic acid, (f) Alpha-linolenic acid, (g) Stearic acid, (h) $\beta$-Amyrin. 


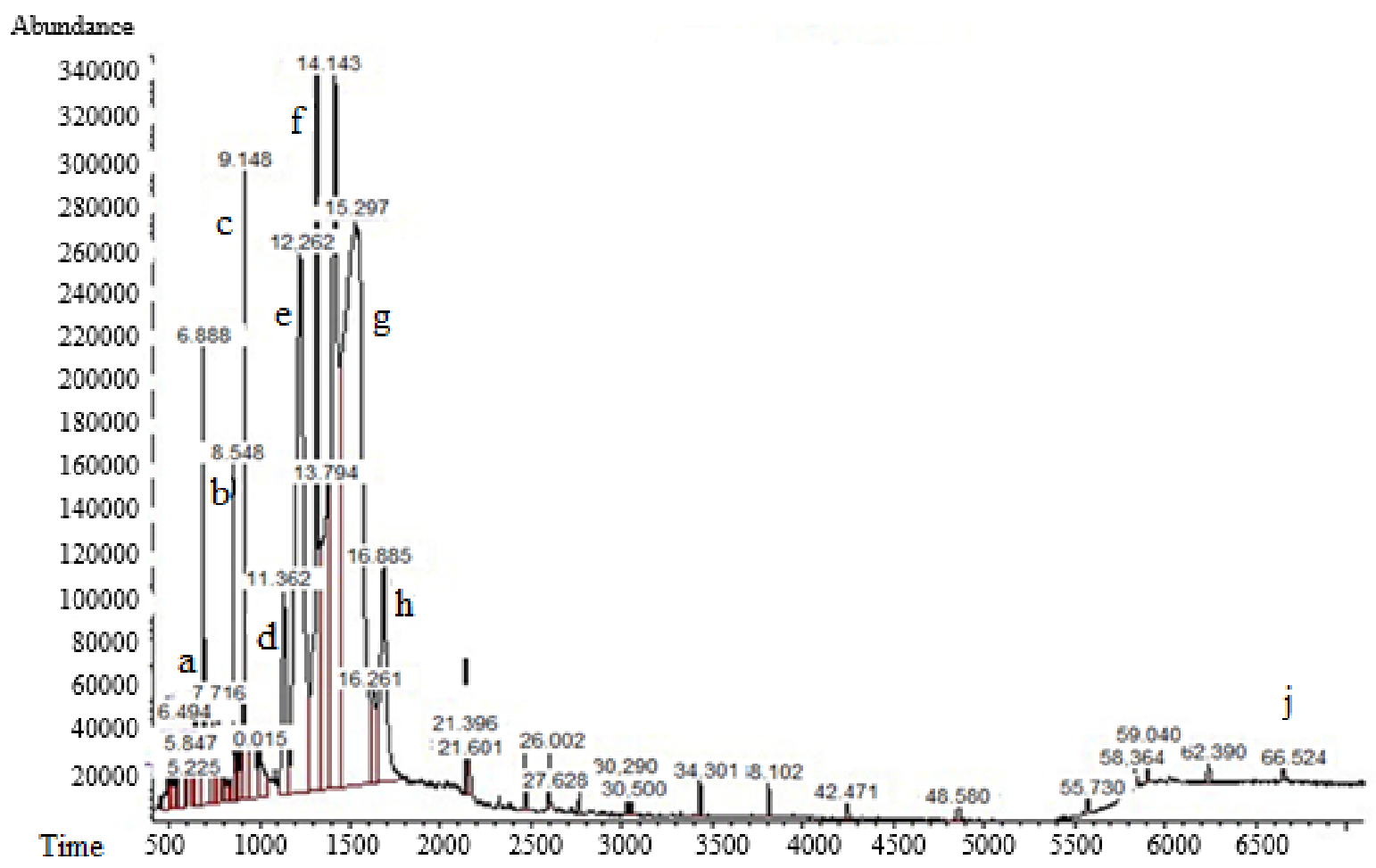

Fig. 2. GC-MS analysis of $V$. album stem extracts. Main components: (a) Phenol, 2,6-dimethoxy, (b) trans-cinnamic acid, (c) Phenol, 3,5-dimethoxy-, (d) Spiro[1,3-dioxolane-2,2'-[7]oxabicyclo[2.2.1]hept[5]ene], ( \pm )-, (e) 1,3,4,5-tetrahydroxy-cyclohexane carboxylic acid, (f) 2-ethyl-1-thia-cyclopentane, (g) Octadecamethylcyclononasiloxane, (h) Mome Inositol, (i) Eicosane, (j) Gibberellic acid.

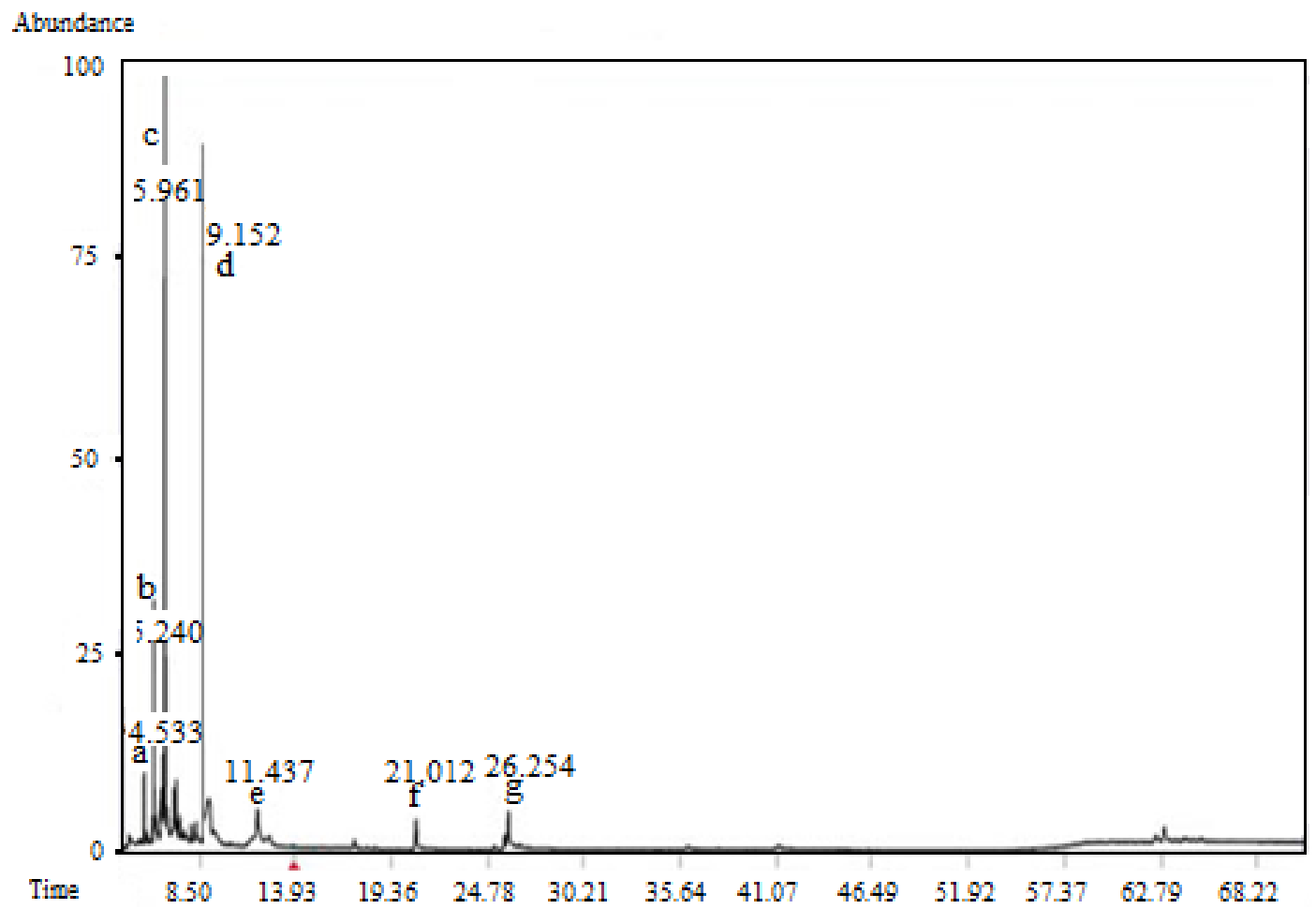

Fig. 3. GC-MS analysis of V. album fruit extracts. Main components: (a) 5-Hidroximetilfurfural, (b) Glucose, (c) Inositol, (d) Palmitic acid, (e) Stearic acid, (f) p-Coumaric acid, (g) Phenols. 
Table 2. GC-MS Analysis of $V$. album leaf extracts.

\begin{tabular}{|c|c|c|c|c|}
\hline Peak & RT & Area $\%$ & Library ID & $\begin{array}{c}\text { Molecular } \\
\text { formula }\end{array}$ \\
\hline 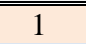 & 8.577 & 4.08 & Trans-cinnamic acid & $\overline{\mathrm{C}_{9} \mathrm{H}_{8} \mathrm{O}_{2}}$ \\
\hline 2 & 9.146 & 2.63 & 3,5-Dimethoxyphenol & $\mathrm{C}_{8} \mathrm{H}_{10} \mathrm{O}_{3}$ \\
\hline 3 & 11.298 & 8.49 & Thiophane, propyl- & $\mathrm{C}_{7} \mathrm{H}_{14} \mathrm{~S}$ \\
\hline 4 & 12.897 & 10.59 & Thiophene D3 & $\mathrm{C}_{4} \mathrm{H}_{4} \mathrm{~S}$ \\
\hline 5 & 13.159 & 4.58 & Xanthoxylin & $\mathrm{C}_{10} \mathrm{H}_{12} \mathrm{O}_{4}$ \\
\hline 6 & 13.789 & 25.23 & Ethoxycitronellal & $\mathrm{C}_{12} \mathrm{H}_{24} \mathrm{O}_{2}$ \\
\hline 7 & 14.727 & 3.23 & methyl $\beta$-D-mannoside & $\mathrm{C}_{7} \mathrm{H}_{14} \mathrm{O}$ \\
\hline 8 & 20.355 & 1.47 & Palmitic acid & $\mathrm{C}_{16} \mathrm{H}_{32}$ \\
\hline 9 & 20.739 & 2.43 & Palmitic acid & $\mathrm{C}_{16} \mathrm{H}_{32}$ \\
\hline 10 & 25.168 & 1.75 & Neophytadiene & $\mathrm{C}_{20} \mathrm{H}_{38}$ \\
\hline 11 & 25.767 & 1.90 & cis-Linoleic acid & $\mathrm{C}_{18} \mathrm{H}_{32}$ \\
\hline 12 & 25.937 & 8.26 & Alpha-linolenic acid & $\mathrm{C}_{18} \mathrm{H}_{30} \mathrm{O}_{2}$ \\
\hline 13 & 26.567 & 2.82 & Stearic acid & $\mathrm{C}_{18} \mathrm{H}_{36}$ \\
\hline 14 & 55.305 & 1.46 & 4-Cyclohexene-1,2-dicarboximide, N-butyl- & $\mathrm{C}_{12} \mathrm{H}_{17} \mathrm{NO}_{2}$ \\
\hline 15 & 55.490 & 1.75 & 5-Nitro-2-benzofurancarboxylic acid & $\mathrm{C}_{9} \mathrm{H}_{5} \mathrm{NO}_{5}$ \\
\hline 16 & 55.997 & 0.87 & Zierone & $\mathrm{C}_{15} \mathrm{H}_{22} \mathrm{O}$ \\
\hline 17 & 59.057 & 1.76 & Propiophenone, 2'-(trimethylsiloxy)- & $\mathrm{C}_{12} \mathrm{H}_{18} \mathrm{O}_{2} \mathrm{Si}$ \\
\hline 18 & 62.594 & 2.19 & Gibberellic acid & $\mathrm{C}_{19} \mathrm{H}_{22} \mathrm{O}_{6}$ \\
\hline 19 & 63.240 & 1.23 & 5(1H)-Azulenone, 2,4,6,7,8,8a-hexahydro-3,8-dimethyl-4-(1-methylethylidene)-, (8S-cis)- & $\mathrm{C}_{15} \mathrm{H}_{22} \mathrm{O}$ \\
\hline 20 & 66.761 & 7.81 & $\beta$-Amyrin & $\mathrm{C}_{30} \mathrm{H}_{50} \mathrm{O}$ \\
\hline 21 & 68.421 & 2.37 & Hexamethylcyclotrisiloxane & $\mathrm{C}_{6} \mathrm{H}_{18} \mathrm{O}_{3} \mathrm{Si}_{3}$ \\
\hline
\end{tabular}

Table 3. GC-MS Analysis of V. album stem extracts.

\begin{tabular}{|c|c|c|c|c|}
\hline Peak & RT & Area $\%$ & Library ID & $\begin{array}{l}\text { Molecular } \\
\text { formula }\end{array}$ \\
\hline 1 & 4.902 & 0.29 & Phenol & $\mathrm{C}_{6} \mathrm{H}_{6} \mathrm{O}$ \\
\hline 2 & 5.056 & 0.32 & 3-Phenoxypropionic acid & $\mathrm{C}_{9} \mathrm{H}_{10} \mathrm{O}_{3}$ \\
\hline 3 & 5.225 & 0.19 & Ethoxybenzene & $\mathrm{C}_{8} \mathrm{H}_{10} \mathrm{O}$ \\
\hline 4 & 5.701 & 0.64 & Phenol, 2-metoxy- & $\mathrm{C}_{7} \mathrm{H}_{8} \mathrm{O}_{2}$ \\
\hline 5 & 5.917 & 0.21 & Thiophene, tetrahydro-3-methyl-2-propyl-, cis- & $\mathrm{C}_{8} \mathrm{H}_{16} \mathrm{~S}$ \\
\hline 6 & 6.347 & 0.44 & Pyrocatechol & $\mathrm{C}_{6} \mathrm{H}_{6} \mathrm{O}_{2}$ \\
\hline 7 & 6.501 & 0.89 & (Ethenyloxy)-benzene0 & $\mathrm{C} 8 \mathrm{H} 8 \mathrm{O}$ \\
\hline 8 & 6.885 & 2.74 & Benzohydroquinone & $\mathrm{C}_{6} \mathrm{H}_{6} \mathrm{O}_{2}$ \\
\hline 9 & 7.362 & 0.60 & 2-methoxy-4-vinyl phenol & $\mathrm{C}_{9} \mathrm{H}_{10} \mathrm{O}_{2}$ \\
\hline 10 & 7.716 & 0.55 & Phenol, 2,6-dimethoxy & $\mathrm{C}_{8} \mathrm{H}_{10} \mathrm{O}_{3}$ \\
\hline 11 & 8.085 & 0.25 & 3-Phenyl-2-Propenoic Acid Methyl & $\mathrm{C}_{10} \mathrm{H}_{10} \mathrm{O}_{2}$ \\
\hline 12 & 8.546 & 1.13 & Trans-cinnamic acid & $\mathrm{C}_{9} \mathrm{H}_{8} \mathrm{O}_{2}$ \\
\hline 13 & 8.731 & 0.33 & 2-Propenoic acid,3-phenyl- & $\mathrm{C}_{9} \mathrm{H}_{8} \mathrm{O}_{2}$ \\
\hline 14 & 8.977 & 0.47 & Thiacyclopentadeca-3,13-diyne & $\mathrm{C}_{14} \mathrm{H}_{20} \mathrm{~S}$ \\
\hline 15 & 9.146 & 2.21 & Phenol, 3,5-dimethoxy- & $\mathrm{C}_{8} \mathrm{H}_{10} \mathrm{O}_{3}$ \\
\hline 16 & 11.360 & 2.54 & Spiro[1,3-dioxolane-2,2'-[7]oxabicyclo[2.2.1]hept[5]ene], $( \pm)-$ & $\mathrm{C}_{8} \mathrm{H}_{10} \mathrm{O}_{3}$ \\
\hline 17 & 12.267 & 14.39 & $1,3,4,5$-Tetrahydroxy-cyclohexanecarboxylic acid & $\mathrm{C}_{7} \mathrm{H}_{12} \mathrm{O}_{6}$ \\
\hline 18 & 13.174 & 5.96 & 2-Hydroxyl-4,6-dimethoxy-acetophenone & $\mathrm{C}_{10} \mathrm{H}_{12} \mathrm{O}_{4}$ \\
\hline 19 & 13.789 & 6.67 & 3,4-Di-O-methyl-L-arabinopyranose & $\mathrm{C}_{7} \mathrm{H}_{14} \mathrm{O}_{5}$ \\
\hline 20 & 14.143 & 14.23 & 2-Ethyl-1-thia-cyclopentane & $\mathrm{C}_{9} \mathrm{H}_{18}$ \\
\hline 21 & 15.296 & 33.80 & Octadecamethylcyclononasiloxane & $\mathrm{C}_{18} \mathrm{H}_{54} \mathrm{O}_{9} \mathrm{Si}_{9}$ \\
\hline 22 & 16.265 & 1.47 & Alpha-d-mannofuranoside,methyl & $\mathrm{C}_{7} \mathrm{H}_{14} \mathrm{O}_{6}$ \\
\hline 23 & 16.865 & 4.34 & Mome Inositol & C7H14O6 \\
\hline 24 & 21.401 & 0.50 & Eicosamethylcyclodecasiloxane & $\mathrm{C}_{20} \mathrm{H}_{60} \mathrm{O}_{10} \mathrm{Si}_{10}$ \\
\hline 25 & 21.601 & 0.28 & Eicosane & $\mathrm{C}_{20} \mathrm{H}_{42}$ \\
\hline 26 & 24.660 & 0.26 & Heneicosane & $\mathrm{C}_{21} \mathrm{H}_{44}$ \\
\hline 27 & 26.014 & 0.32 & Hexadecamethylcyclooctasiloxane & $\mathrm{C}_{16} \mathrm{H}_{64} \mathrm{O}_{8} \mathrm{Si}_{8}$ \\
\hline 28 & 27.628 & 0.10 & Nonadecane & $\mathrm{C}_{19} \mathrm{H}_{40}$ \\
\hline 29 & 30.288 & 0.18 & Hexadecamethylheptasiloxane & $\mathrm{C}_{16} \mathrm{H}_{48} \mathrm{O}_{6} \mathrm{Si}_{7}$ \\
\hline 30 & 30.504 & 0.12 & Hexatriacontane & $\mathrm{C}_{36} \mathrm{H}_{74}$ \\
\hline 31 & 34.301 & 0.17 & Silikonfett SE30(Grevels) & - \\
\hline 33 & 42.466 & 0.17 & Silicone grease, siliconfett & - \\
\hline 34 & 48.586 & 0.18 & Tetracosamethylcyclododecasiloxane & $\mathrm{C}_{24} \mathrm{H}_{96} \mathrm{O}_{12} \mathrm{Si}_{12}$ \\
\hline 35 & 55.736 & 0.16 & 4H-Dibenz[de,g]isoquinoline,5,6,6a,7-tetrahydro-1,2,9,10-tetramethoxy-5-methyl- & $\mathrm{C}_{21} \mathrm{H}_{25} \mathrm{NO}_{4}$ \\
\hline 36 & 58.365 & 0.26 & Cyclotrisiloxane, hexamethyl- & $\mathrm{C}_{6} \mathrm{H}_{18} \mathrm{O}_{3} \mathrm{Si}_{3}$ \\
\hline 37 & 62.394 & 0.17 & 1,2-Bis(trimethylsilyl)benzene & $\mathrm{C}_{12} \mathrm{H}_{22} \mathrm{Si}_{2}$ \\
\hline 38 & 66.515 & 0.16 & Gibberellic acid & $\mathrm{C}_{19} \mathrm{H}_{22} \mathrm{O}_{6}$ \\
\hline
\end{tabular}


Table 4. GC-MS Analysis of V. album fruits extracts.

\begin{tabular}{|c|c|c|c|c|}
\hline Peak & RT & Area \% & Library ID & Molecular formula \\
\hline 1 & 4.533 & 15.16 & 5-Hidroximetilfurfural & $\mathrm{C}_{6} \mathrm{H}_{6} \mathrm{O}_{3}$ \\
\hline 2 & 5.240 & 10.05 & Glucose & $\mathrm{C}_{6} \mathrm{H}_{12} \mathrm{O}_{6}$ \\
\hline 3 & 5.961 & 15.70 & Inositol & $\mathrm{C}_{7} \mathrm{H}_{14} \mathrm{O}_{6}$ \\
\hline 4 & 9.152 & 1.53 & Palmitic acid & $\mathrm{C}_{16} \mathrm{H}_{32}$ \\
\hline 5 & 11.437 & 1.80 & Stearic acid & $\mathrm{C}_{18} \mathrm{H}_{36}$ \\
\hline 6 & 21.012 & 1.72 & p-Coumaric acid & $\mathrm{C}_{9} \mathrm{H}_{8} \mathrm{O}_{3}$ \\
\hline 7 & 26.254 & 1.78 & Phenol & $\mathrm{C}_{6} \mathrm{H}_{6} \mathrm{O}$ \\
\hline 8 & 62.765 & 0.30 & Gibberellic acid & $\mathrm{C}_{19} \mathrm{H}_{22} \mathrm{O}_{6}$ \\
\hline
\end{tabular}

The dichloromethane: methanol extract at concentrations of 150,200 , and $250 \mathrm{mg} / \mathrm{ml}$ showed the highest inhibition on E. faecalis ATCC 29212. All extracts prepared at concentrations 150, 200, and 250 $\mathrm{mg} / \mathrm{ml}$ were found to be effective on $P$. aeruginosa PA14. We found that the dichloromethane: methanol extract at concentrations from 100 to $250 \mathrm{mg} / \mathrm{ml}$ prevented spread of Klebsiella pneumoniae ATCC 700603 with the zones ranging from $11-15 \mathrm{~mm}$. The efficacy of dichloromethane:methanol extracts at concentrations of 100, 150, 200 and $250 \mathrm{mg} / \mathrm{ml}$ was higher on Klebsiella pneumoniae ATCC 700603 strain than E. coli O157: H7. Different concentrations of $V$. album extracts were also found to stop the growth of L. monocytogenes ATCC 7644 (8-13mm), B. cereus RSKK 863 (7-13mm), S. epidermitis wt $(9-13 \mathrm{~mm})$, and $P$. aeruginosa ATCC 27853 (10-13mm) (Table 6).

According to the antimicrobial activity analysis results, the highest antimicrobial effect was observed in dichloromethane: methanol extracts for all plant parts tested. Therefore, anti-biofilm and anti-quorum sensing assays were performed using dichloromethane: methanol extracts. The lowest concentration of fruit extract for biological activity was determined as $150 \mathrm{mg} / \mathrm{ml}$. Therefore, anti-quorum sensing and anti-biofilm tests were performed at a concentration of $100 \mathrm{mg} / \mathrm{ml}$ in accordance with the concentration of leaf and stem extracts. When we analyzed the antimicrobial activity of dichloromethane: methanol extracts of fruit, we found that the maximum effect was on E. faecalis ATCC 29212 with a zone diameter of $15 \mathrm{~mm}$. Klebsiella pneumoniae ATCC 700603 and E. coli O157: H7 are among the most inhibited species by the fruit extracts.

The fruit extract $(150 \mathrm{mg} / \mathrm{ml})$ was found to be less effective against $P$. aeruginosa PA14 (10 mm inhibition zone). The fruit extracts of prepared with ethanol and chloroform resulted in an inhibition of 5-9 $\mathrm{mm}$. It was also proved that DMSO solution selected as the control had no effect on any of the strains. When our results are evaluated in general, it is clear that the extracts whose antibacterial activities were tested have inhibitory effects on the bacterial strains included in the study. The antimicrobial activities of different concentrations of $\mathrm{N}$-hexane extracts of $V$. album L. subsp. abietis (Wiesb.) was investigated on Candida albicans (Robin) Berkhout, Bacillus subtilis (Ehrenberg) Chon, Staphylococcus aureus Rosenbach, Escherichia coli Escherich, Pseudomonas aeruginosa (Schröter) Mihgula,
Enterobacter cloacae (Jordan) Hormaeche \& Edwards, and Proteus vulgaris and the $6^{\text {th }}$ and $7^{\text {th }}$ hexane fractions were found to be effective (Ertürk et al. 2004).

The antimicrobial activities of dichloromethane, chloroform, and water extracts of Viscum capense L. were tested against Staphylococcus aureus, Pseudomonas aeruginosa, and Candida albicans (Amabeoku et al. 1998). The results showed that the chloroform extract inhibited the growth of $S$. aureus, whereas it was not effective on other microorganisms.

As a result of the present study, $V$. album extracts were found to be effective on 3-oxo-C6-HSL which is a bacterial communication molecule used by many Gram-negative pathogenic bacteria. C. violaceum $\mathrm{CV} 026$ is a mini $\mathrm{Tn}-5$ mutant of C. violaceum ATCC 31532 (Mc Clean et al. 1997). The mutant produces violacein pigment when 3oxo-C6-HSL is in the medium. It was seen that violacein pigment production was reduced using both agar diffusion test (zone formation) and the extraction of violacein pigment from broth medium when the Viscum extract was released into the medium. We came to the conclusion that this molecule was affected as a result of these tests. The dichloromethane: methanol extracts of stem, leaf and fruit of $V$. album showed promising anti-quorum sensing activity, and a clear white opaque zone of inhibition was observed in the biosensor plate containing the reference strain C. violaceum CV026 (Fig. 4).

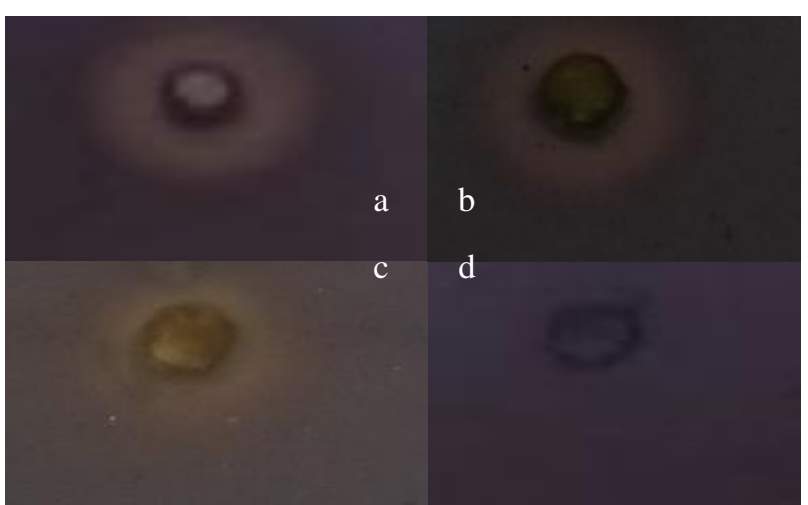

Fig. 4. Inhibition of violacein production by (a) fruit, (b) leaf, and (c) stem extracts in dichloromethane: methanol using Chromobacterium violaceum CV026 biomonitor strain and the agar well diffusion method. The inhibition was detected by a colorless, opaque halo around the discs. (d) DMSO was used as control. In accordance with the data acquired from well diffusion studies, the pigment isolation of violacein is carried out to understand the inhibition of the signal molecule (Fig. 5). 
Therefore, it is possible to suggest that the interception of bacterial communication by $V$. album extracts can bring a new perspective to antimicrobial studies.

The production of violacein by $C$. violaceum $\mathrm{CV} 026$ was inhibited by dichloromethane: methanol extracts of leaf, stem, and fruits (Fig. 5). The presence of plant extracts had no influence on the growth of $C$. violaceum CV026. The violacein production and cell counts were similar in the control group with solvents (Group B) and the group without solvent (Group A).

Viscum album was reported to be highly effective on both bacteria and fungi (Dulger \& Gonuz 2004). The components of $V$. album were proved to be effective as anti-diabetic and anti-hyperlipidemic in diabetic rats, which supports the use in traditional medicine (Adaramoye et al. 2012). The positive effect on lipid profile in diabetic rats eliminates secondary complications of diabetes. Önay-Uçar et al. (2012) stated that chloroform extracts of $V$. album can inhibit oxidative DNA damage, and that biological activity of $V$. album depends on its host tree.

The biological activity (anti-tumor and anti-bacterial) of the European mistletoe $V$. album collected from 13 different host trees was evaluated by (Turker et al. 2012). The water extract of the plants collected from Prunus divaricata Ledeb. showed the best antitumor activity (87.3\% inhibition). The anti-quorum sensing activity of $E$. angustifolia extracts were determined in another study (Erdonmez et al. 2016). In our study, V. album was also collected from Elaeagnus angustifolia L. as the host plant. When the results of effects of $V$. album extracts are compared with the effects of $E$. angustifolia extracts, it is seen that the extracts of $V$. album are more efficient than the extracts of E. angustifolia on QS process. Even so, $V$. album may contain the chemical components of its host and these components may increase the biological activity of V. album.

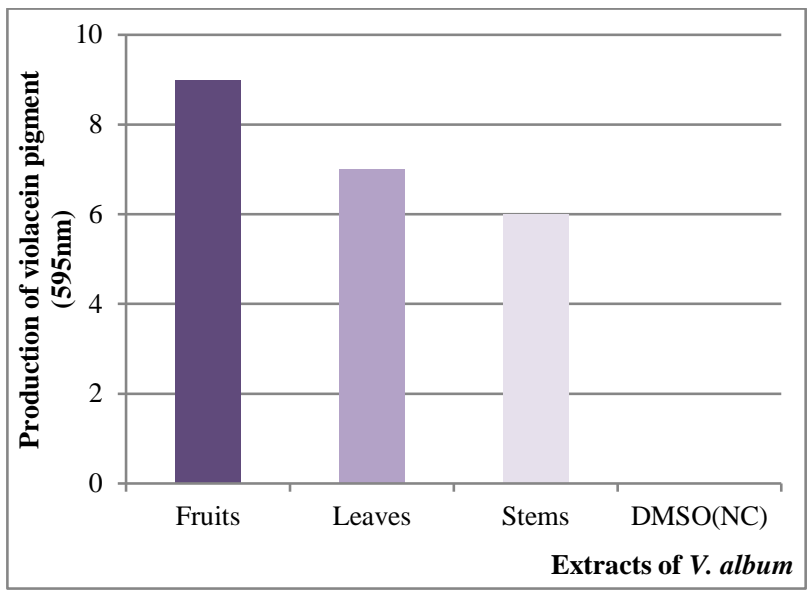

Fig. 5. Inhibition of violacein production by Chromobacterium violaceum CV026.

In future, the prevention of bacterial communication by the help of plant extracts instead of anti-microbial activity will increase the chance of success in infectious diseases. Anti-quorum sensing activity of $V$. album may play an important role in antibacterial activity, and therefore, it ensures an extra strategy in the struggle against bacterial infections. However, molecular researches are needed to explain the mechanism of antibacterial activity completely.

Many studies showed that the biofilm formation by pathogens leads to an increase in their virulence (Vuong et al. 2004, Antunes et al. 2010). Therefore, if the biofilm formation is inhibited, the bacterial infection can be prevented.

Table 5. Growth inhibition activity of $V$. album fruit exracts against the pathogenic bacteria tested.

\begin{tabular}{|c|c|c|c|c|c|c|c|c|c|}
\hline \multirow{2}{*}{ Exracts $(150 \mathrm{mg} / \mathrm{ml})$} & \multicolumn{9}{|c|}{ Zone of inhibition (mm) } \\
\hline & 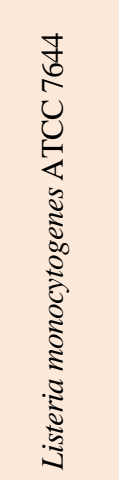 & 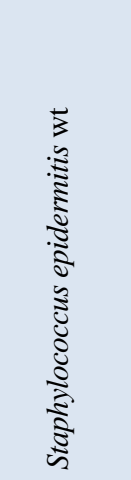 & 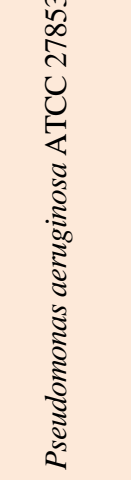 & 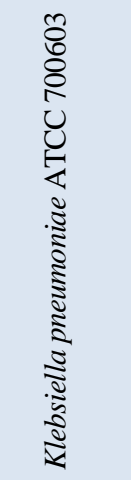 & 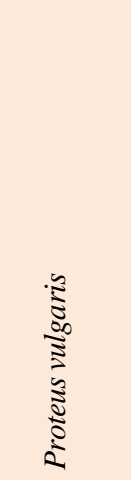 & 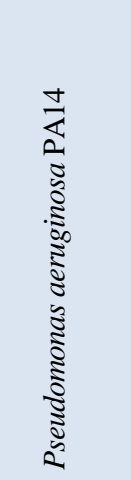 & 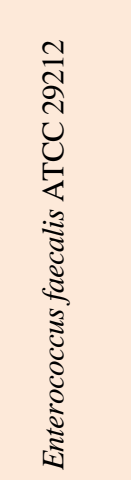 & 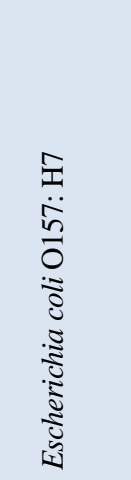 & 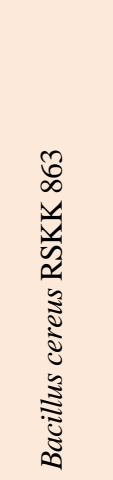 \\
\hline$\overline{\text { Ethanol }}$ & $7 \pm 0.40$ & $\overline{5 \pm 0.50}$ & $7 \pm 0.04$ & $6 \pm 0.24$ & $8 \pm 0.27$ & $6 \pm 0.24$ & $6 \pm 0.33$ & $8 \pm 0.20$ & $5 \pm 0.08$ \\
\hline Chloroform & $8 \pm 0.24$ & $7 \pm 0.33$ & $7 \pm 0.04$ & $8 \pm 0.40$ & $9 \pm 0.20$ & $7 \pm 0.040$ & $8 \pm 0.27$ & $6 \pm 0.24$ & $7 \pm 0.04$ \\
\hline Dichloromethane: methanol & $10 \pm 0.51$ & $12 \pm 0.50$ & $11 \pm 0.13$ & $14 \pm 0.90$ & $13 \pm 0.33$ & $10 \pm 0.55$ & $15 \pm 0.40$ & $14 \pm 0.50$ & $12 \pm 0.48$ \\
\hline DMSO & 0 & 0 & 0 & 0 & 0 & 0 & 0 & 0 & 0 \\
\hline
\end{tabular}

$\overline{0, \text { no inhibition, DMSO, dimethylsulfoxide, } \pm \text { Standard deviation }}$ 
Table 6. Growth inhibition activity of $V$. album stem and leaf extracts against the pathogenic bacteria tested.

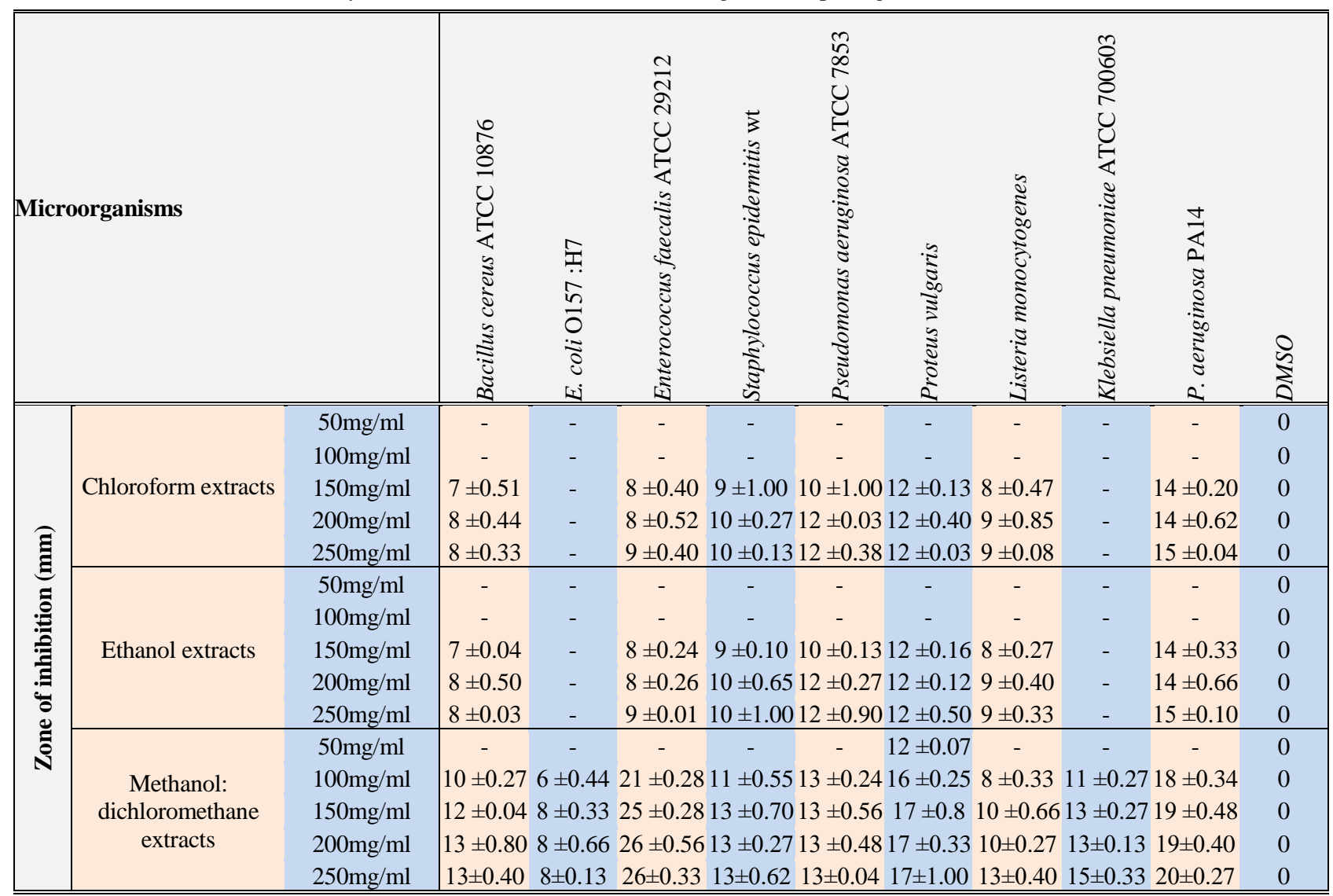

0 , no inhibition, DMSO, dimethylsulfoxide, \pm Standard deviation

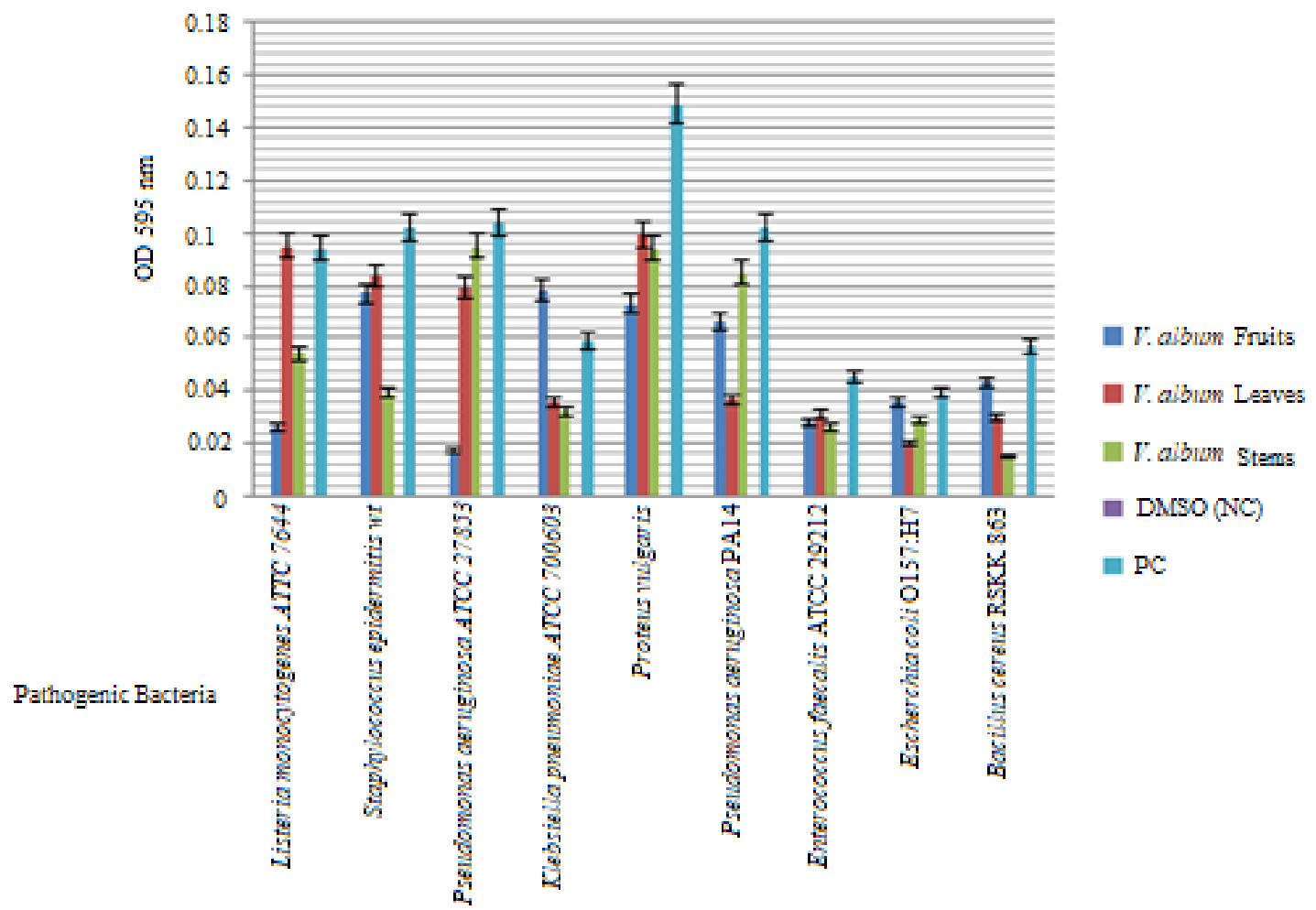

Fig. 6. The effect of Viscum album extracts in reducing biofilm formation in Listeria monocytogenes ATCC 7644, Staphylococcus epidermitis wt, Pseudomonas aeruginosa ATCC 27853, Klebsiella pneumoniae ATCC 700603, Proteus vulgaris, Pseudomonas aeruginosa PA14, Enterococcus faecalis ATCC 29212, Escherichia coli O157: H7, Bacillus cereus RSKK 863. 
Nowadays, biological materials are mostly preferred for use in the inhibition methods of biofilm formation and also in protection against bacterial infections (Rutherford \& Bassler 2012). Although many antimicrobial studies of $V$. album are available in literature, no studies related to antibiofilm and anti-quorum sensing activity of this species has been carried out (Chandrashekhara et al. 2010, Hussain et al. 2011, Kotan et al. 2013, Nawrot et al. 2014, Sadananda et al. 2014).

Some plant extracts were reported to show antibiofilm activity by inhibiting the initial phase of biofilm formation and growth (Sandasi et al. 2008). Our results showed that $V$. album extracts were highly effective in degrading the biofilm activity of Listeria monocytogenes ATCC 7644, Staphylococcus epidermitis wt, Pseudomonas aeruginosa ATCC 27853, Klebsiella pneumoniae ATCC 700603, Proteus vulgaris, Pseudomonas aeruginosa PA14, Enterococcus faecalis ATCC 29212, Escherichia coli O157: H7, and Bacillus cereus RSKK 863 (Fig. 6). The formation of bacterial biofilm decreased after the addition of plant extracts. A decrease ranging from $20 \%$ to $80 \%$ depending on the extract used was recorded in the spectrophotometric measurements. The effects of biofilm inhibition of leaf and stem extracts were higher than effects of fruit extracts.

Bazargani \& Rohloff (2016) investigated the vitro anti-biofilm activities of essential oils and plant extracts

\section{References}

1. Adaramoye, O., Amanlou, M., Habibi-Rezaei, M., Pasalar, P. \& Ali, M.-M. 2012. Methanolic extract of African mistletoe (Viscum album) improves carbohydrate metabolism and hyperlipidemia in streptozotocin-induced diabetic rats. Asian Pacific Journal of Tropical Medicine, 5(6): 427-433.

2. Adonizio, A.L., Downum, K., Bennett, B.C. \& Mathee, K. 2006. Anti-quorum sensing activity of medicinal plants in southern Florida. Journal of Ethnopharmacology, 105(3): 427-435.

3. Amabeoku, G.J., Leng, M.J. \& Syce, J.A. 1998. Antimicrobial and anticonvulsant activities of Viscum capense. Journal of Ethnopharmacology, 61(3): 237-241.

4. Antunes, L.C.M., Ferreira, R.B., Buckner, M.M. \& Finlay, B.B. 2010. Quorum sensing in bacterial virulence. Microbiology, 156(8): 2271-2282.

5. Arda, N., Onay, E., Koz, O. \& Kirmizigul, S. 2003. Monosaccharides and polyols from mistletoes (Viscum album $\mathrm{L}$ ) growing on two different host species. BiologiaBratislava, 58(6): 1037-1042.

6. Bazargani, M.M. \& Rohloff, J. 2016. Antibiofilm activity of essential oils and plant extracts against Staphylococcus aureus and Escherichia coli biofilms. Food Control, 61: 156-164.

7. Bezek, K., Kurinčič, M., Knauder, E., Klančnik, A., Raspor, P., Bucar, F. \& Smole Možina, S. 2016. Attenuation of Adhesion, Biofilm Formation and Quorum Sensing of Campylobacter jejuni by Euodia ruticarpa. Phytotherapy research, 30(9): 1527-1532. of Coriandrum sativum L. through Crystal Violet (CV) and XTT tests and found that the plant extracts and their essential oils could reduce the bacterial biofilm at a rate of $50 \%$ and that the activity of essential oils of coriander was particularly high. The ethanol extract of stem bark of Terminalia fagifolia Mart. showed a distinct biofilm inhibition, and it could block biofilm formation of some strains above $80 \%$ (de Araujo et al. 2015). Stem, leaf and fruits of $V$. album contain very large amounts of phytochemicals such as flavonoids, alkaloids, steroids, glycosides, and phenols showing that $V$. album is suitable for medical use.

In conclusion, this study demonstrated that V. album extracts are remarkable anti-biofilm agents against biofilm formed by pathogens and inhibit signal molecules, which form the basis of bacterial communication mechanism.

\section{Acknowledgement}

This study was financially supported by Aksaray University Department of Scientific Research Projects Coordination (Project Number: 2016-055). We would like to thank Dr. Gülşah Göçmen (Aksaray-Turkey) for her helps in improving the language of an earlier version of the manuscript.

8. Brackman, G. \& Coenye, T. 2015. Quorum sensing inhibitors as anti-biofilm agents. Current Pharmaceutical Design, 21(1): 5-11.

9. Bussing, A. 2003. Mistletoe: The Genus Viscum. Harwood Academic Publishers, Amsterdam.

10. Büssing, A. \& Schietzel, M. 1999. Apoptosis-inducing properties of Viscum album L. extracts from different host trees, correlate with their content of toxic mistletoe lectins. Anticancer research, 19(1A): 23-28.

11. Chandrashekhara, Niranjan Raj, S., Manjunath, G., Deepak, S. \& Shekar Shetty, H. 2010. Seed treatment with aqueous extract of Viscum album induces resistance to pearl millet downy mildew pathogen. Journal of Plant Interactions, 5(4): 283-291.

12. Chung, P.Y. \& Toh, Y.S. 2014. Anti-biofilm agents: recent breakthrough against multi-drug resistant Staphylococcus aureus. Pathogens and disease, 70(3): 231-239.

13. Davis, P.H. 1965. Flora of Turkey, Vol 1-10. Edinburgh University Press, Edinburgh.

14. de Araujo, A.R., Quelemes, P.V., Perfeito, M.L.G., de Lima, L.I., Sá, M.C., Nunes, P.H.M., Joanitti, G.A., Eaton, P., Soares, M.J.d.S. \& de Souza de Almeida Leite, J.R. 2015. Antibacterial, antibiofilm and cytotoxic activities of Terminalia fagifolia Mart. extract and fractions. Annals of Clinical Microbiology and Antimicrobials, 14(1): 25.

15. Deliorman, D., Çalış, I. \& Ergun, F. 2001. A new acyclic monoterpene glucoside from Viscum album ssp. album. Fitoterapia, 72(2): 101-105. 
16. Dulger, B. \& Gonuz, A. 2004. Antimicrobial activity of some Turkish medicinal plants. Pakistan Journal of Biological Sciences, 7(9): 1559-1562.

17. Erdonmez, D., Kenar, N. \& Turkmen, K.E. 2016. Evaluation of anti-quorum sensing activity of Elaeagnus angustifolia L. extracts from Central Anatolia. Journal of Biotechnology, 231: 34 .

18. Ergun, F. \& Deliorman, D. 1995. Viscum album L. (Ökse otu) Bitkisinin Kimyasal Bileşimi. Journal of Faculty of Pharmacy of Ankara University, 24(2): 21-33.

19. Eroğlu, M. \& Usta, M. 1993. Viscum album L.'un Sarıçam Artımına Odunun Kimyasal ve Morfolojik Özelliklerine Etkisinin Araştırılması. II Ulusal Orman Ürünleri Endüstrisi Kongresi, 1(1): 116-122.

20. Ertürk, Ö., Kati, H., Yayli, N. \& Demirbağ, Z. 2004. Antimicrobial activity of Viscum album L. subsp. abietis (Wiesb). Turkish Journal of Biology, 27(4): 255-258.

21. Ghuman, S., Ncube, B., Finnie, J.F., McGaw, L.J., Coopoosamy, R.M. \& Van Staden, J. 2016. Antimicrobial Activity, Phenolic Content, and Cytotoxicity of Medicinal Plant Extracts Used for Treating Dermatological Diseases and Wound Healing in KwaZulu-Natal, South Africa. Frontiers in Pharmacology, 7, 320.

22. Gray, A. \& Flatt, P. 1999. Insulin-secreting activity of the traditional antidiabetic plant Viscum album (mistletoe). Journal of Endocrinology, 160(3): 409-414.

23. Güner, A. 2012. Türkiye Bitkileri Listesi (Damarlı Bitkiler). Nezahat Gökyiğit Botanik Bahçesi ve Flora Araştırmaları Derneği Yayını, İstanbul.

24. Habeck, M. 2003. Mistletoe compound enters clinical trials. Drug discovery today, 8(2): 52-53.

25. Hoffman, L.R., D'Argenio, D.A., MacCoss, M.J., Zhang, Z., Jones, R.A. \& Miller, S.I. 2005. Aminoglycoside antibiotics induce bacterial biofilm formation. Nature, 436(7054): 1171-1175.

26. Hussain, M.A., Khan, M.Q., Hussain, N. \& Habib, T. 2011. Antibacterial and antifungal potential of leaves and twigs of Viscum album L. Journal of Medicinal Plants Research, 5(23): 5545-5549.

27. Karagöz, A., Önay, E., Arda, N. \& Kuru, A. 2003. Antiviral potency of mistletoe (Viscum album ssp. album) extracts against human parainfluenza virus type 2 in Vero cells. Phytotherapy Research, 17(5): 560-562.

28. Kaya, M., Sargin, I. \& Erdonmez, D. 2016. Microbial biofilm activity and physicochemical characterization of biodegradable and edible cups obtained from abdominal exoskeleton of an insect. Innovative Food Science \& Emerging Technologies, 36: 68-74.

29. Khan, M.S.A., Zahin, M., Hasan, S., Husain, F. M., Ahmad, I. 2009. Inhibition of quorum sensing regulated bacterial functions by plant essential oils with special reference to clove oil. Letters in applied microbiology, 49(3): 354-360.

30. Kotan, R., Okutucu, A., Ala Görmez, A., Karagoz, K., Dadasoglu, F., Karaman, I., Hasanekoglu, I. \& Kordali, Ş. 2013. Parasitic bacteria and fungi on common mistletoe (Viscum album L.) and their potential application in biocontrol. Journal of Phytopathology, 161(3): 165-171.
31. Martinelli, L., Rosa, J.M., Ferreira, C.D.S.B., Nascimento, G.M.D.L., Freitas, M.S., Pizato, L.C., Santos, W.D.O., Pires, R.F., Okura, M.H. \& Malpass, G.R.P. 2017. Antimicrobial activity and chemical constituents of essential oils and oleoresins extracted from eight pepper species. Ciência Rural, 47(5): e20160899.

32. McClean, K.H., Winson, M.K., Fish, L., Taylor, A., Chhabra, S.R., Camara, M., Daykin, M., Lamb, J.H., Swift, S., Bycroft, B.W. and Stewart, G.S., 1997. Quorum sensing and Chromobacterium violaceum: exploitation of violacein production and inhibition for the detection of $\mathrm{N}$ acylhomoserine lactones. Microbiology, 143(12), 37033711.

33. Musthafa, K., Ravi A., Annapoorani, A., Packiavathy, I.V. \& Pandian, S. 2010. Evaluation of anti-quorum-sensing activity of edible plants and fruits through inhibition of the $\mathrm{N}$-acyl-homoserine lactone system in Chromobacterium violaceum and Pseudomonas aeruginosa. Chemotherapy, 56(4): 333-339.

34. Nawrot, R., Barylski, J., Nowicki, G., Broniarczyk, J., Buchwald, W. \& Goździcka-Józefiak, A. 2014. Plant antimicrobial peptides. Folia microbiologica, 59(3): 181196.

35. Nazaruk, J. \& Orlikowski, P. 2016. Phytochemical profile and therapeutic potential of Viscum album L. Natural Product Research, 30(4): 373-385.

36. O'Toole, G.A. 2011. Microtiter dish biofilm formation assay. Journal of Visualized Experiments, (47): e2437e2437.

37. Ogunmefun, O., Fasola, T., Saba, A. \& Oridupa, O. 2013. The ethnobotanical, phytochemical and mineral analyses of Phragmanthera incana (Klotzsch), a species of mistletoe growing on three plant hosts in South-Western Nigeria. International journal of biomedical science, 9(1): 33.

38. Oliveira, B.D.Á., Rodrigues, A.C., Cardoso, B.M.I., Ramos, A.L.C.C., Bertoldi, M.C., Taylor, J.G., da Cunha, L.R. \& Pinto, U.M. 2016. Antioxidant, antimicrobial and anti-quorum sensing activities of Rubus rosaefolius phenolic extract. Industrial Crops and Products, 84: 59-66.

39. Rumbaugh, K.P., Diggle, S.P., Watters, C.M., RossGillespie, A., Griffin, A.S. \& West, S.A. 2009. Quorum sensing and the social evolution of bacterial virulence. Current Biology, 19(4): 341-345.

40. Rutherford, S.T. \& Bassler, B.L. 2012. Bacterial quorum sensing: its role in virulence and possibilities for its control. Cold Spring Harbor perspectives in medicine, 2(11): a012427.

41. Sadananda, T., Govindappa, M. \& Ramachandra, Y. 2014. In vitro antioxidant activity of lectin from different endophytic fungi of Viscum album L. British Journal of Pharmaceutical Research, 4(5): 626.

42. Sánchez, E., Rivas Morales, C., Castillo, S., Leos-Rivas, C., García-Becerra, L. \& Ortiz Martínez, D.M. 2016. Antibacterial and Antibiofilm Activity of Methanolic Plant Extracts against Nosocomial Microorganisms. EvidenceBased Complementary and Alternative Medicine, 2016: 1572697.

43. Sandasi, M., Leonard, C.M. \& Viljoen, A.M. 2008. The effect of five common essential oil components on Listeria 
monocytogenes biofilms. Food Control, 19(11): 10701075.

44. Sengul, M., Yildiz, H., Gungor, N., Cetin, B., Eser, Z. \& Ercisli, S. 2009. Total phenolic content, antioxidant and antimicrobial activities of some medicinal plants. Pakistan Journal of Pharmaceutical Sciences, 22(1): 102-106.

45. Stepanović, S., Vuković, D., Dakić, I., Savić, B. \& ŠvabićVlahović, M. 2000. A modified microtiter-plate test for quantification of staphylococcal biofilm formation. Journal of microbiological methods, 40(2): 175-179.

46. Stoss, M. \& Gorter, R.W. 1998. No evidence of IFN- $\gamma$ increase in the serum of HIV-positive and healthy subjects after subcutaneous injection of a non-fermented Viscum album L. extract. Natural immunity, 16(4): 157-164.
47. Turker, A.U., Yıldırım, A.B. \& Karakas, F.P. 2012. Antitumor and antibacterial activities of Viscum album L. grown on different host trees. Spatula DD, 2: 229-236.

48. Tusenius, K., Spoek, J. \& Kramers, C. 2001. Iscador Qu for chronic hepatitis C: an exploratory study. Complementary therapies in medicine, 9(1): 12-16.

49. Vuong, C., Kocianova, S., Voyich, J.M., Yao, Y., Fischer, E.R., DeLeo, F.R. \& Otto, M. 2004. A crucial role for exopolysaccharide modification in bacterial biofilm formation, immune evasion, and virulence. Journal of Biological Chemistry, 279(52): 54881-54886.

50. Waters, C.M. \& Bassler, B.L. 2005. Quorum sensing: cellto-cell communication in bacteria. Annual review of cell and developmental biology, 21: 319-346. 
